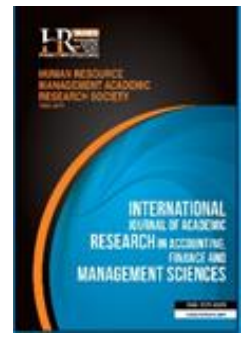

International Journal of Academic Research in Accounting, Finance and Management Sciences

Vol. 8, No.2, April 2018, pp. 200-207

E-ISSN: 2225-8329, P-ISSN: 2308-0337

(c) 2018 HRMARS

www.hrmars.com

To cite this article: Kasasbeh, I. (2018). Problems of Management Accounting Implementation. The Case of Balanced Scorecard Implementation within Jordanian Commercial Banks, International Journal of Academic Research in Accounting, Finance and Management Sciences 8 (2): 200-207.

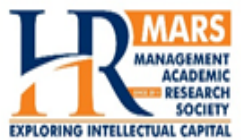

http://dx.doi.org/10.6007/IJARAFMS/v8-i2/4271 (DOI: 10.6007/IJARAFMS/v8-i2/4271)

\title{
Problems of Management Accounting Implementation: The Case of Balanced Scorecard Implementation within Jordanian Commercial Banks
}

Islam KASASBEH

Islamic Finance Department. University of Jordan, Jordan, Email: islamkasasbeh1@gmail.com

Abstract

This study aimed to find the status of Balanced Scorecard implementation in Jordanian Commercial Banks and the most barriers and problems of BSC implementation in these banks. The results indicated that the Jordanian banks used a set of financial and non-financial performance measures which are similar and consistent with the Balanced Scorecard dimensions. The fully implementation rate was $30.7 \%$ of the Jordanian Commercial Banks. The results from the semi-structured interviews shows that the barriers and problems of BSC implementation in these banks are social issues such as lack of Top management support and organizational culture, technical issues such as data gathering and automation, political issues such as resistance from employees, a lack of software packages, and employees turnover. Conceptual issues also mentioned by the interviewed banks as a problem to the implantation of BSC such as the misunderstandings about the relationship between the organizational strategy and the BSC scorecard, and BSC is a "general model" which may be not easy to fit any bank.

Key words

Balanced Scorecard, problems, Implementation, Jordanian banks

Received: 10 Jun $2018 \quad$ (C) The Authors 2018

Revised: 28 Jun 2018 Published by Human Resource Management Academic Research Society (www.hrmars.com

Accepted: $\quad 30$ Jun 2018 This article is published under the Creative Commons Attribution (CC BY 4.0) license. Anyone may reproduce, distribute, translate and create derivative works of this article (for both commercial and noncommercial purposes), subject to full attribution to the original publication and authors. The full terms of this license may be seen at: http://creativecommons.org/licences/by/4.0/legalcode

\section{Introduction}

After a huge change in businesses environment such as internationalization and globalization competition became a very important issue for most of the companies around the world. This important change pushes many companies for using new management accounting innovation such as JIT, $A B C$, and BSC. Many advantages for using these new management innovation but its implementation around the world is still low (Faudziah and Rababah 2011; Fadzil and Rababah, 2011, 2012; Upton, 2012; Rababah and Hasan, 2012; Alsawalqa et al., 2011; Rabab'ah, 2013; Hasan, 2017 and Rababah, 2017).

Balanced scorecard introduced at the beginning by Kaplan and Norton in 1992 to overcome of the shortfalls of the old financial-based performance indicators. The BSC combines the traditional performance measures that depend on financial performance with operational measures and non-financial measure. The BSC performance measures contain four categories namely financial, customer-related, internal business processes, and learning and growth (Upton, 2012). the reasons for shifting to BSC because BSC use financial non financial performance measures, financial measure is not enough to measure the performance because any management can manipulate with numbers to reach short-term results while forsaking longterm performance.

The balanced scorecard is a tool to show the balance between short and long-term objectives in the organization, between financial and non-financial measures, between indicators that are lagging and leading and finally, between perspectives of external and internal performance (Kaplan and Norton, 1996). 
BSC implementation is very beneficial in measuring the company's performance but the implementation rate of this innovation is still low (Al Sawalqa et al., 2011; Rabab'ah, 2014; Rababah and Bataineh, 2016 and Ondieki, 2017). The majority of businesses applying the BSC think that it is only work for a short period. In actuality, less than $20 \%$ of organizations applying the BSC have recognized computable performance enhancement (Williams, 2004; Rababah, 2015). In this regard Madsen and Stenheim (2014) said: "Although many BSC success stories have been cited in the practitioner-oriented literature and in the business media, researchers have shown that the implementation of BSC can be a complicated process. There are many pitfalls and dysfunctional consequences associated with the implementation and use of the BSC."

Previous studies (such as; Wenisch, 2004; Rabab'ah, 2014; Madsen and Stenheim, 2014 and Rababah 2015) paid attention to know the factors that influence to the implementation of BSC. Wenisch (2004) conducted a qualitative study to explore the factors which influence to the implementation of BSC during the top-down implementation process, he found that motivators would have an impact on the first adoption decision not on the process whereas facilitator such as IT and catalyst factors that can be directly associated with change process; for instance, fashion perspective. Rababah (2015) found that cultural factors such as Innovation and Attention to Detail play a significant role in determining the success or failure of BSC implementations.

Previous studies show a lack of studies tried to know the problems or the reasons of nonimplementation of BSC (Tayler 2010). Some studies such as Rabab'ah (2014) conducted a research in Jordanian companies to know the implementation rate and the factors which influence to the implementation of BSC. he found that the reasons for implementing BSC system in Jordanian companies all Abrahamson four perspectives which are Fad, Fashion, Efficiency choice and Forced decision. He found also that changing the business environment, Top management support and information technology is the mainly important factor to influence BSC implementation. He mentioned some problems encountered the implementation these are "high cost of installing and maintaining the system followed by the lack of information to implement BSC, Resistance from employees, a lack of software packages supporting the BSC, and there were misunderstandings about the relationship between the espoused organizational strategy and the BSC scorecard."

Madsen and Stenheim (2014) conducted a qualitative study within Scandinavian BSC users companies to know the problems of BSC implementation, they found four problem areas related to the implementation of the BSC, these problems are firstly, conceptual issues which mean understanding the more complex part of the BSC idea, like how to adjust and adapt the standard BSC model to fit the organization. Second, technical issues are linked to technical infrastructure, software and too much focus on measurement. Third, social issues are related to inappropriateness between the BSC and the organizational culture, lack of contribution by the employees, and lack of loyalty from the top management. Finally, political issues are associated with underestimation of time and resources necessary to apply the concept, lack of a concept champion, difficulties in keeping continuity during bad times, and different types of organizational resistance to the concept.

The purpose of this paper is to introduce empirical evidence about what BSC users perceive to be the key problems associated with BSC implementation and help managers to avoid the implementation problems in the future. The paper adds to the literature on BSC implementation issues (Kasurinen, 2002; Rabab'ah, 2014; Madsen and Stenheim, 2014). Earlier studies such as Al Sawalqa et al. (2011), recommended that future studies should try to explore the problems encountering the BSC implementation. This study focused on Jordanian Commercial Banks sector because Jordanian banks face a sharp competition coming from foreign banks in Jordan, added to that a significant changes witnessed by the banking business in recent years, these changes are also attributed to have led to management accounting practices changes in Jordan. Earlier studies focused only on the implementation of BSC in western developed countries. This study contributes to the further development of knowledge in management accounting and provides a basis for further research in Jordan (Rabab'ah, 2014). This paper used a qualitative method to collect the data from the consultants and managers involved in BSC implementation projects in Jordanian Banks to know what is the current state of BSC implementation and the most barriers and problems which face this implementation. 


\section{Literature Revier}

\subsection{Balanced Scorecard}

The Balanced Scorecard was the result of studies and the efforts of scientists in the field of management and business with the development of modern managerial thought and the concept of quality and knowledge management.

Balanced Scorecard: Is a strategic planning tool to help organizations assess their activities, performance and strategies, and takes into account the balance between financial results and growth, the balance between the short and long term, and the balance between tactics and strategy. It is also possible to say that Balanced Scorecard is not only a measurement system but an administrative system that links objectives, metrics and target levels, which describes the strategy of origin and helps it to provide management with feedback on its internal processes and external products. This model was developed in 1996 by Kaplan and Norton.

Balanced Scorecard Axes :Balanced Scorecard is based on four main axes, measuring the overall performance of the organization as follows:

Financial: Contains financial objectives, such as return on investment, profitability, cash flow, economic value added and cost of products.

Customers: Related to the quality of customer service, market share, and customer satisfaction; such as fulfilling their desires by offering new products and services and responding to customer needs.

Internal business process: It is concerned with the development of internal processes, such as the development of administrative systems and cooperation between different departments. And maintain the global performance of the organization, such as innovations in new processes in product design and development.

Learning and growth: Determines the capacities in which the organization must grow to achieve high-level internal processes for customers and shareholders.

Earlier studies mentioned many benefits to the implementation of BSC for instances Ashton (1998) the BSC can be used as:

- To translate the data in the company into a strategy to be followed by employees to reach the best results and achieve long term success

- A tool for linking business, team and individual objectives and rewards to strategic goals.

- A way to understand the drivers of business success.

- An identifier of "cause-and-effect" relationships across operations.

- A dynamic communication and a feedback tool.

Although there is no prove that BSC users is better performance than non-user a recent study by Hussain, Aledwan, and Zreqat (2017) found a significant differences in the use of every performance measurement and the financial performance.

\subsection{Barriers and Problems of BSC Implementation}

Although the is a lack of studies related to the problems of BSC in banks, earlier studies mention some barriers and problems for the implementation of BSC for example Ismail (2007) conducted a study within Egyptian Companies and he found that insufficiency of information systems and lack of information about BSC implementation, lack of management enthusiastic towards non-financial measures, significant costs for the acquisition and maintenance of performance evaluation systems, ambiguous company strategies and insufficient software packages to support BSC. In this regard a study by Thompson and Mathys' (2008) shows four main barriers to BSC implementation. The first one is the lack of understanding of the organizational processes; second, ignorance about the requirement of items which fit BSC; third, lack of organizational understanding of the need for suitable metrics; and finally, misunderstandings about the espoused organizational strategy-BSC scorecard relationship. A study by Rabab'ah (2014) in Jordan, he mentioned some problems met the implementation of BSC such as "high cost of installing and maintaining the system followed by the lack of information to carry out BSC, resistance from employees, a lack of software packages supporting the BSC, and there were misunderstandings about the relationship between the espoused organizational strategy and the BSC scorecard". 
Based to Madsen and Stenheim (2014), they said that "there are four problems associated with the implementation of the Balanced Scorecard these problems summarized in the next table.

Table 1. Four categories of problems associated with BSC implementation

\begin{tabular}{|c|c|c|}
\hline Issue type & Problem & Explanation \\
\hline \multirow{3}{*}{$\begin{array}{l}\text { Conceptual } \\
\text { issues }\end{array}$} & Contextualization & $\begin{array}{l}\text { The BSC is a "general model" which may be difficult to } \\
\text { customize to fit the organization }\end{array}$ \\
\hline & Causal relationships & $\begin{array}{l}\text { Organizations struggle with understanding and testing causal } \\
\text { relationships }\end{array}$ \\
\hline & Strategy maps & $\begin{array}{l}\text { Organizations have problems with data gathering and } \\
\text { automation, or become too focused on the } \\
\text { technical aspects of the concept }\end{array}$ \\
\hline $\begin{array}{l}\text { Technical } \\
\text { issues }\end{array}$ & Technical issues & $\begin{array}{l}\text { Organizations have problems with data gathering and } \\
\text { automation, or become too focused on the } \\
\text { technical aspects of the concept }\end{array}$ \\
\hline \multirow{3}{*}{ Social issues } & Organizational culture & $\begin{array}{l}\text { The BSC may be incompatible with the organizational culture, } \\
\text { e.g. lack of acceptance of } \\
\text { measurement }\end{array}$ \\
\hline & Participation & $\begin{array}{l}\text { Organizational members remain passive and delay or block the } \\
\text { implementation process }\end{array}$ \\
\hline & Commitment & $\begin{array}{l}\text { Lack of commitment from central actors in the organization, } \\
\text { such as the top management group or } \\
\text { the BSC project group }\end{array}$ \\
\hline \multirow{4}{*}{$\begin{array}{l}\text { Political } \\
\text { issues }\end{array}$} & Time and resources & $\begin{array}{l}\text { The implementation of the BSC consumes a lot of time and } \\
\text { resources }\end{array}$ \\
\hline & Concept champion & $\begin{array}{l}\text { The organization lacks a person that is spearheading the BSC } \\
\text { project }\end{array}$ \\
\hline & Continuity & The continuity of the BSC project is threatened by turnover \\
\hline & Resistance & Organizational members resist the implementation of the BSC \\
\hline
\end{tabular}

Source: Madsen and Stenheim (2014)

Previous studies shows a lack of studies related to the main problems which encountered during balanced scorecard implementation in banks sector so, we will try to investigate in this issues in the current study.

\subsection{Jordanian Commercial Banks}

Based on the Central Bank of Jordan, the number of banks in Jordan is twenty-five banks, including fifteen Jordanian banks, two of them are Islamic banks and the remaining are commercial banks, in addition to ten foreign banks one of them are Islamic bank. The following table shows the List of banks in Jordan.

Table 2. List of banks in Jordan

\begin{tabular}{|l|l|l|}
\hline \multicolumn{1}{|c|}{ List of Banks in Jordan } & \multicolumn{1}{|c|}{ Commercial Banks } & \multicolumn{1}{|c|}{ Islamic Banks } \\
\hline Jordanian Banks & Arab Bank & Jordan Islamic Bank \\
& ABC Bank (Jordan) & Jordan Dubai Islamic Bank \\
& Bank of Jordan & \\
& Cairo Amman Bank & \\
& Capital Bank & \\
& Jordan Commercial Bank & \\
& Jordan Kuwait Bank & \\
& Jordan Ahli Bank & \\
& The Housing Bank for Trade and Finance & \\
& Arab Jordan Investment Bank & \\
& Invest Bank & \\
& Société Générale & \\
& Bank al Etihad & \\
\hline
\end{tabular}




\begin{tabular}{|l|l|l|}
\hline \multicolumn{1}{|c|}{ List of Banks in Jordan } & \multicolumn{1}{|c|}{ Commercial Banks } & \multicolumn{1}{|c|}{ Islamic Banks } \\
\hline Foreign Banks in Jordan & European Bank for Reconstruction and & Al-Rajhi Bank \\
& Development \\
Standard Chartered & \\
& Egptian Arab Lank Bank & \\
& HSBC & \\
& Citibank & \\
& Rafidain Bank & \\
& National Bank of Kuwait & \\
& BLOM Bank & \\
& Bank Audi & \\
& National Bank of Abu Dhabi & \\
\hline
\end{tabular}

In the current study we will conduct our study on the Jordanian commercial banks because the Islāmic banks follow a specific culture in their operations and privacy performance measures, as well as an exception of the foreign banks in Jordan because the major central management are located outside Jordan.

\section{Methodology of research}

Mixed method was used in the current study, 13 surveys were distributed within the Jordanian commercial banks licensed in the Central Bank to know the implementation status in Jordanian banks. The distribution was within main branch or any branch for each bank. This process took place from 8th January to 1st February 2018. All questionnaires filled by the financial managers in each bank. A hand delivery were made to increase the response rate. This is followed by semi-structured interviews conducted with financial managers/assistant financial managers of banks in Jordan. This study analyzes the data collected from interviews with representatives of five banks that have now implemented BSC approach to find the barriers and problems of BSC implementation. The data analysis depended on both within company and cross company analysis. This method used by many previous studies in management accounting filed such as Ahmad and Rbaba (2014).

\subsection{Data analysis}

The findings in this study enhance the body of knowledge in this area of research. The study combined questionnaire and interviews methods to investigate the BSC implementation in Jordanian Commercial Banks.

\subsection{Quantitative Data Analysis}

Based on the results of the questionnaire survey, Jordanian banks are classified about the implementation of BSC as follows:

Table 3. Number of Banks in each category of BSC implementation

\begin{tabular}{|c|c|}
\hline Name of the Stage & Number of the Banks \\
\hline Fully Implementers & 4 \\
\hline Partially Implementers & 9 \\
\hline Non- Implementers & 0 \\
\hline
\end{tabular}

Based on the above results the BSC fully implementation rate in the Jordanian banks is $30.7 \%$ measured according to the number of fully implementers banks within Jordanian commercial banks.

\subsection{Qualitative Data Analysis}

This section describes within-company analysis and Cross-company Analysis for partially and fully implementers banks. It provides a summary of background information which gives overall problems of each bank. Then it provides an outline of a cross-company analysis. It includes all barriers and problems identified by the banks managers. 
The fifth banks interviewed faced problems regarding the implementation of BSC. In all Banks, there is strong evidence that the conceptual issues, technical issues, social issues and political issues which introduced by Madsen and Stenheim (2014) are associated with BSC implementation within the Jordanian banks. Most of the respondents from the participating banks (five banks out of five) said that Social issues such as lack Top management support are the mainly important barriers to influence BSC implementation. (Three banks out of five) said that Social issues such as organizational culture and lack of acceptance of measurement are significant barriers to the implementation of BSC. This finding is consistent with the more general finding implying that almost all successful innovations require top management support. Hence, top management should concentrate on resources, goals and strategies in BSC implementation and they must obvious their promise to BSC by using the information it provides as the basis for decision-making. The companies agreed also that Technical issues such as data gathering and automation was the mainly significant barriers to the implementation of BSC. Through BSC implementation process, the organization could be faced with problems related to Political issues such as Resistance from employees, a lack of software packages supporting the BSC, and employees' turnover. Four banks out of five said that Resistance from employees is an important problem during the implementation of BSC. This followed by three banks out of five said that a lack of software packages and employees' turnover is a problems influencing to the implementation of BSC in Jordanian Banks. Conceptual issues also mentioned by the interviewed banks as a problem to the implantation of BSC such as the misunderstandings about the relationship between the organizational strategy and the BSC scorecard. Three banks out of five said that BSC is a "general model" which may be not easy to fit any bank.

\section{Conclusions}

This paper used mixed method from questionnaires and semi-structured interviews to know the BSC implementation status, and to find out the barriers and problems of BSC implementation. The data analysis shows that multiple types of problems influence to the implementation of BSC in Jordanian bank. Social issues mentioned as the most important problem faced the banks before and during the implementation of BSC especially lack Top management support. This result is consistent with Rabab'ah (2014) who found that Top management support is the mainly important factor to influence BSC implementation in Jordanian companies. Organizational culture is a significant barrier to the implementation of BSC mentioned in Jordanian Commercial Banks because some of Jordanian employees have different measurement to the bank performance then there is a lack of acceptance of BSC measurement. This result is consistent with Rababah (2015) who said that Cultural factors play an important role in determining the success or failure of BSC implementations. Technical issues such as data gathering and automation were the mainly important barriers to the implementation of BSC. This result is consistent with Madsen and Stenheim (2014) who found the same result. Through BSC implementation process, the organization could be faced with problems related to Political issues such as resistance from employees, a lack of software packages supporting the BSC, and employees' turnover. This result was consistent with earlier studies such as Madsen and Stenheim (2014) and Rabab'ah (2014). Conceptual issues also mentioned by the interviewed banks as a problem to the implantation of BSC such as the misunderstandings about the relationship between the organizational strategy and the BSC scorecard. In addition, BSC is a "general model" which may be not easy to fit any bank.

\section{Recommendations and Suggestions for Future Research}

Balance Scorecard is more beneficial measurement than traditional financial measurement but its implementation rate is still low because many barriers and problems facing the implementation. However, the main implementation barriers are still unclear. In this paper, I found some barriers and problems facing the implementation of BSC in Jordanian Commercial Banks, these problems were lack Top management support, organizational culture, data gathering and automation resistance from employees, a lack of software packages, and employee's turnover.

The number of Banks in each stage of BSC implementation is small. This presented difficulties in conducting meaningful statistical tests. In other words, the results of the current study may have turned out in a different way if the number of banks in each stage was higher. The current study is focused only on 
Jordanian Commercial Banks; this study limitation may adversely affect the findings generalizability. Therefore, a more expanded research ground is called for in future research for the gaining a wide information about other banks about BSC implementation problems (within Jordan and in other countries). I recommended that future studies should conduct a deeply studies using a case study method with user's banks, to know the most important problems that really facing the banks during the implementation.

\section{References:}

1. Ahmad, B. and Rbaba (2014). Activity Based Costing Systems in Jordanian Manufacturing Companies. Journal of Modern Management and Entrepreneurship. 4(1), 27-39.

2. Al-Sawalqa. F; Holloway, D; andAlam, M, (2011). Balanced Scorecard Implementation In Jordan: An Initial Analysis. ; International Journal of Electronic Business Management, Vol. 9, No. 3, pp. 196-210 (2011).

3. Ashton, C. (1998). Balanced Scorecard Benefits NatWest Bank. International Journal of Retail and Distribution Management, 26 (10), 400-401.

4. Davis, S., and Albright, T. (2004). An investigation of the effect of balanced scorecard implementation on financial performance. Management accounting research, 15(2), 135-153.

5. Faudziah, K.and Rababah, L. (2011). Adoption and implementation of activity based costing system in Jordanian manufacturing companies. Published at the International Business Information Management Conference (17th IBIMA). Milan, Italy.

6. Fadzil, F. H., and Rababah, A. (2011) The Conceptual Study Regarding ABC System Implementation: Evidence From Jordanian Companies. International Postgraduate Business Journal (IPBJ). Vol. 3 (2), $1-13$.

7. Fadzil, F. H. B. and Rababah, A. 2012. Management Accounting Change: ABC Adoption and Implementation. Journal of Accounting and Auditing: Research and Practice, 2012, 1-17.

8. Hasan, A. (2017). Implementation Problems of Activity Based Costing: A Study of Companies in Jordan. British Journal of Economics, Management and Trade 17 (1), 1-9.

9. Hoque, Z., and James, W. (2000). Linking balanced scorecard measures to size and market factors: impact on organizational performance. Journal of management accounting research, 12(1), 1-17.

10.Hussain, L. F. M., Aledwan, B. A. Zreqat, Omar M. (2017); The Extent of Applying the Balanced Scorecard in the Jordanian Banks, and its Effects on Performance; Journal of Social Sciences (COESandRJJSS), Vol.6, No.3, pp:532-547; https://doi.org/10.25255/jss.2017.6.3.532.547.

11.Ismail, T. H., (2007). Performance evaluation measures in the private sector: Egyptian practice, Managerial Auditing Journal, Vol. 22, No. 5, pp. 503-513.

12.Kaplan, R. S. and Norton, D. P (1992). The Balanced Scorecard: Measures that drive performance. The Harvard Business Review, 70(1), pp. 71-80. - (1996).

13.Kasurinen, T. (2002). Exploring management accounting change: The case of balanced scorecard implementation, Management Accounting Research (September), pp. 323-343.

14.Madsen, D. $\varnothing$., andStenheim, T. (2014). Perceived problems associated with the implementation of the balanced scorecard: evidence from Scandinavia.

15.Ondieki, E. M. (2017). The Effect Of The Balanced Scorecard On Organizational Performance In The Public Sector In Kenya: A Case Of Kenya Bureau Of Standards, Summer 2017. United States International University -Africa.

16.Rababah, A., and Hasan, A. (2012). The Implementation Stage of Activity Based Costing Systems in Jordanian Manufacturing Shareholding Companies (Doctoral dissertation, Universiti Utara Malaysia).

17.Rbaba'h, A., (2013). The influence of Company Characteristics Factors to Activity Based Costing System Implementation. Journal of Education and Vocational Research, 4 (2): pp. 36-46. - (2014). The Implementation of Management Accounting Innovations "The Case of Balanced Scorecard Implementation within Jordanian Manufacturing Companies", International Review of Management and Business Research, 3(1), 174-181.

18.Rababah, A. (2015). The Relationship between Cultural Factors and Balanced Scorecard Implementation, International Review of Management and Business Research, 4(4), 1208 - 1218. - (2017). 
Nanotechnology and Accounting Issues. Risk governance and control: financial markets and institutions, 7(2,1), 224-230. http://dx.doi.org/10.22495/rgcv7i2c1p10

19. Rababah, A. and Bataineh, A. (2016). "Factors Influencing Balanced Scorecard Implementation". Research Journal of Finance and Accounting .Vol.7, No.2, pp. 204-212.

20.Tayler, W.B. (2010). The Balanced Scorecard as a Strategy-Evaluation Tool: The Effects of Implementation Involvement and a Causal-Chain Focus, The Accounting Review, 85 (3), pp. 1095-1117.

21.Thompson, K. R. and Mathys, N. J. (2008). “The aligned balanced scorecard: An improved tool for building high performance organizations, "Organizational Dynamics, Vol. 37, No. 4, pp.378-393.

22.Madsen, D. $\varnothing$.; Stenheim, T. (2014). Perceived problems associated with the implementation of the balanced scorecard: Evidence from Scandinavia. Probl. Perspect. Manag. 2014, 12, 121-131.

23.Upton, D; (2012). Experimental Balanced Scorecard Research: Implications for Practitioners. Management Accounting Quarterly.Vol.13, No.4.

24.Wenisch, S. (2004).The Diffusion of a Balanced Scorecard in a Divisionalized Firm-Adoption and Implementation in a practical context. Umeå: Umeå University Press.

25.Williams, K. (2004, November). What constitutes a successful Balanced Scorecard? Strategic Finance, 86(5), pp.19-20.

26.Jordanian banks Council, Annual Report, number of reports. 